\title{
Study of the distribution and depletion of chloramphenicol residues in bee products extracted from treated honeybee (Apis mellifera L.) colonies*
}

\author{
Stuart J. ADAMS ${ }^{1}$, Katharina HEINRICH ${ }^{1}$, Richard J. FUSSELL ${ }^{1}$, Selwyn WILKINS ${ }^{2}$, \\ Helen M. THOMPSON ${ }^{2}$, Helen M. AshwIN ${ }^{1}$, Matthew SHARMAN ${ }^{1}$ \\ ${ }^{1}$ Food Science Group, Central Science Laboratory, Sand Hutton, York, YO41 1LZ, UK \\ ${ }^{2}$ National Bee Unit, Central Science Laboratory, Sand Hutton, York, YO41 1LZ, UK
}

Received 6 December 2007 - Revised 2 May 2008 - Accepted 16 May 2008

\begin{abstract}
Bee colonies were dosed with chloramphenicol (CAP) 1.0 g per hive (single dose in sucrose solution). Samples of honey were then collected at intervals over a 48-week period and samples of royal jelly, beeswax, honeybees and brood collected at intervals over a 12 week period. The mean concentration of CAP in the honey at 7 days after dosing was $26 \mu \mathrm{g} / \mathrm{g}$, declining to $1.0 \mu \mathrm{g} / \mathrm{g}$ at 332 days. Application of the shook swarm procedure resulted in a mean concentration of CAP in honey of $26 \mu \mathrm{g} / \mathrm{g}$ at 7 days, declining to $0.1 \mu \mathrm{g} / \mathrm{g}$ at 332 days. The mean concentration of CAP in non-honey samples was in the range of 0.5 to $6.8 \mu \mathrm{g} / \mathrm{g}$, and 0.2 to $3.3 \mu \mathrm{g} / \mathrm{g}$ at 7 days and 56 days, respectively. These results indicate that use of CAP can be detected up to 332 days after dosing even if the shook swarm procedure is used in an attempt to clean the hives. There was no evidence of any significant formation of bound CAP-glucose conjugates in honey.
\end{abstract}

chloramphenicol / honey / bees / royal jelly / beeswax

\section{INTRODUCTION}

Chloramphenicol (CAP) is a broadspectrum antibiotic, which inhibits protein synthesis in a variety of aerobic and anaerobic bacteria. The use of CAP in human health care is restricted to treating conditions such as typhoid fever, bacterial meningitis and conjunctivitis. CAP has been identified as a cause of aplastic anaemia, a rare and serious blood disorder, resulting in the failure of bone marrow to produce blood cells. For these reasons it has been prohibited from use in food-producing animals, including honey bees, in the United States of America, Canada and the EU. CAP is listed as a prohibited substance for use in food producing animals with an Annex IV classification under European legislation (Council Regulation 2377/90)

Corresponding author: S.J. Adams,

s.adams@csl.gov.uk

* Manuscript editor: Jean-Noël Tasei with a zero tolerance policy. The Minimum Required Performance Limit (MRPL) for CAP analysis is $0.3 \mu \mathrm{g} / \mathrm{kg}(0.0003 \mu \mathrm{g} / \mathrm{g})$ as set out in Commission Decision 2003/181/EC.

There is evidence that CAP is effective in controlling Paenibacillus larvae larvae which can cause American Foulbrood Disease (AFB) (Kochansky et al., 2001) and it has been used for this purpose. In a recent survey $97 \%$ of samples of honey from China contained residues of CAP (Verzegnassi et al., 2003). Similarly a high incidence of CAP residues has been reported in royal jelly (Calvarese et al., 2006; Ishh et al., 2006). Surveys in the UK detected CAP residues in imported honey in 2002, 2003 and 2004 (Veterinary Medicines Directorate Non-Statutory Surveillance programme) but no residues were detected in a retail survey of honey (Veterinary Residues Committee, 2006).

Despite these findings and reported methods for the analysis of CAP in honey 


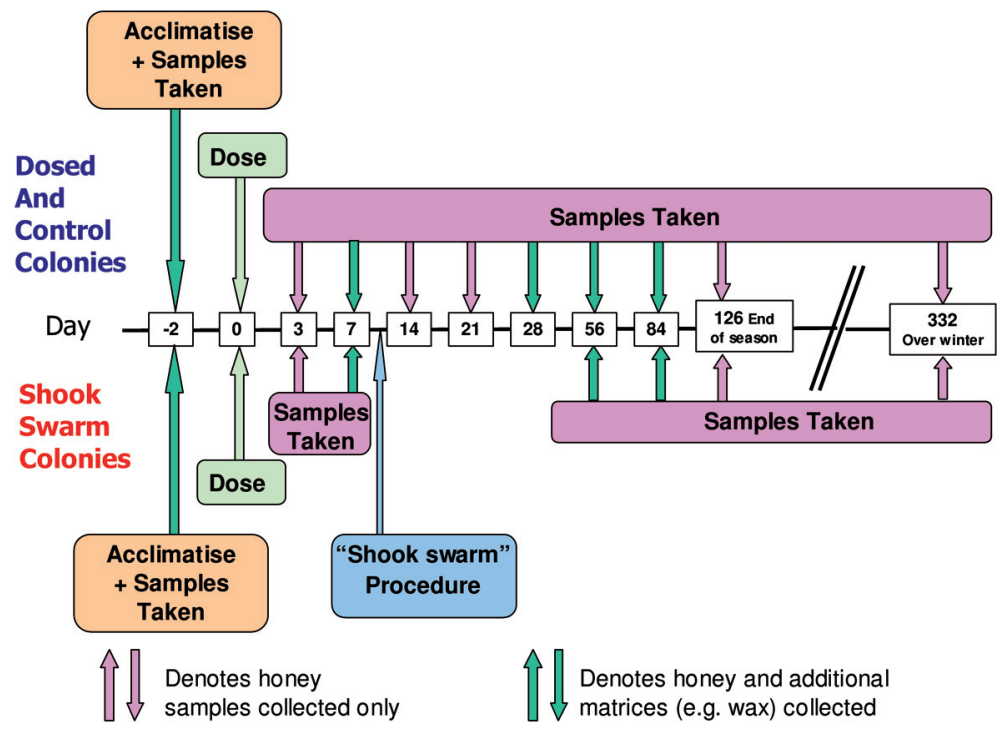

Figure 1. Sampling plan for honey from the 8 experimental hives.

(McMullen et al., 2004; Ashwin et al., 2005) and royal jelly (Fujita et al., 2005; Wen et al., 2005) knowledge on the distribution and depletion of CAP in bee products from bee colonies dosed with CAP is limited. The main purpose of the study described here was to investigate the distribution and depletion of CAP in bee colonies dosed with CAP. The results provide information on the persistence of CAP and the likelihood of detecting the use of CAP in apiculture. This project also investigated the use of the shook swarm procedure as a potential method for residue reduction in an attempt to avoid detection by current analytical techniques.

\section{METHODS AND MATERIALS}

\subsection{Bee colonies and treatments}

The dosing study was carried out during June 2004-May 2005. Eight standardised free flying colonies of UK honeybees (Apis mellifera L.), housed in double Smith brood boxes with 11 British standard frames $(33.6 \mathrm{~cm}$ by $20.4 \mathrm{~cm}$ giving $685.4 \mathrm{~cm}^{2}$ per side of brood frame) per brood box and at least one super box, with 18-20 frames of bees in each colony, were used in this study. The colonies were maintained and owned by the Central Science Laboratory (CSL), National Bee
Unit (NBU). At the start of the trial these colonies showed no clinical signs of European or American foulbrood, sacbrood or baldbrood, and had only a low incidence of chalkbrood. Six colonies were treated with chloramphenicol. These were located at an experimental apiary approximately $10 \mathrm{~km}$ from two non-dosed control colonies that were established in parallel at the CSL site to reduce the risk of cross-contamination by drifting.

The six treated colonies were dosed with a solution of $1.0 \mathrm{~g}$ of chloramphenicol in $200-250 \mathrm{~mL}$ aqueous sucrose solution $(50-60 \% \mathrm{w} / \mathrm{v})$ by pouring into a marked empty brood frame, which was placed in the top brood box; two frames in, usually on the edge of the brood nest with the treated side of the frame out. The two control colonies were fed with untreated sucrose using the same method of application. Seven days after dosing and collection of honey and non-honey samples, two of the treated colonies were randomly selected and shook swarmed. The shook swarm treatment involves the transfer of the adult bees onto clean foundation with the brood, stored honey and original frames being removed and destroyed. During winter (after sample collection in October) the colonies were fed with $50 \% \mathrm{w} / \mathrm{v}$ sucrose using a rapid tray feeder.

\subsection{Sampling}

The sampling plan employed is outlined in Figure 1. In June 2004, two to four days (D-2 to D-4) 
before treatment, samples (honey, royal jelly, bees, brood and wax) were taken from each colony to establish a baseline concentration for the colonies, i.e. to confirm antibiotic residues were not present. Samples were collected as described below.

At each sampling point, honeycomb samples (approximately $8 \mathrm{~cm}$ by $10 \mathrm{~cm}$, with up to $25 \mathrm{~g}$ of honey each) were taken from four individual frames; two from the brood chamber and two from the super of each hive. For each colony these samples were bulked as super sources and brood chamber sources. The honey samples were extracted by filtering through cloth (mesh size approx $0.25 \mathrm{~mm} \times$ $0.25 \mathrm{~mm}$ ) into a clean container. All samples were stored at $-20{ }^{\circ} \mathrm{C}$ prior to analysis. Samples of wax (approximately $10 \mathrm{~g}$ ) were also collected from the freshly drawn combs. The wax remaining after the removal of the honey was retained as the wax sample.

Royal jelly was collected from artificial queen cells. Approximately 10 larvae (3-4 days old) were grafted into artificial plastic queen cell cups. These were introduced into the colonies above the queen excluder and left for three days for the larvae to be fed and raised as queens. On the third day (sample point D3) the entire queen cell cup was removed from the hive. This was repeated to allow collection of royal jelly samples at D7, D28, D56 and D84.

Adult bee samples (containing $50-100$ bees) were collected from the super frames, above the queen excluder. Bees were shaken from the comb into a hive roof and collected in a sample tube. When this was not possible bees were collected from the brood combs in the same manner. Samples of brood comprised sections containing 100-200 larvae/pupae (i.e. both unsealed and sealed brood) were cut from brood frames in the lower brood chamber of the hive.

At the end of the trial (after the over winter samples had been collected) bees from all treated colonies were shaken onto new foundation and all of the used brood and super combs incinerated.

CAP free samples of royal jelly, beeswax, adult bees and brood, for use in method development and analysis, were supplied by the NBU.

\subsection{Apparatus and reagents}

Chloramphenicol (TLC grade) was purchased from Sigma Aldrich (Dorset, UK). Chloramphenicol - d5 (98\% purity) was purchased from Cambridge Isotope Laboratories (Massachusetts,
USA). Chem Elut (5 mL) cartridges and Bond Elut $\mathrm{NH}_{2} \mathrm{SPE}$ (Solid Phase Extraction) cartridges ( $3 \mathrm{~mL}, 0.2 \mathrm{~g}$ ) were purchased from Varian (Oxford, UK). Enzymes $\alpha$-Glucosidase from Bacillus stearothermophilus, $\alpha$-Glucosidase from Saccharomyces cerevisiae and $\beta$-Glucosidase from almonds were purchased from Sigma Aldrich (Dorset, UK). HBS-EP buffer was purchased from Biacore AB (Stevenage, UK). All other reagents were of analytical grade and obtained from Fisher Scientific (Loughborough, UK).

\subsubsection{Preparation of standard solutions}

Stock standards of CAP $(1 \mathrm{mg} / \mathrm{mL})$ and CAP-d5 $(10 \mu \mathrm{g} / \mathrm{mL})$ were prepared in methanol and stored at $-20^{\circ} \mathrm{C}$.

\subsection{Extraction method for honey}

Samples of honey $(0.5 \mathrm{~g})$ were diluted in water $(10 \mathrm{~mL})$. The samples were then washed with dichloromethane $(5 \mathrm{~mL})$ and centrifuged at $3000 \mathrm{rpm}$ for 10 minutes at room temperature. An aliquot $(0.5 \mathrm{~mL})$ water was removed for dilution into HPS-EP buffer solution $(4.5 \mathrm{~mL})$. If required samples were further diluted in HPS-EP buffer solution accordingly to bring the concentration into the linear range for the biosensor employed for quantification (Sect. 2.9.1). No internal standard was used in this method.

\subsection{Extraction methods for non-honey matrices}

Chloramphenicol - d5 (internal standard) was added to all samples immediately before extraction. Samples of honeybees, beeswax and brood were extracted and analysed in duplicate. Samples of royal jelly were extracted singly due to the limited amount of sample available.

\subsubsection{Extraction method for royal jelly}

Samples of royal jelly $(0.5 \mathrm{~g})$ were diluted in $30 \%$ water in acetonitrile $(4.5 \mathrm{~mL})$ and mixed on a flat bed shaker set at $350 \mathrm{rpm}$ for 10 minutes. The water/acetonitrile solution was retained for the clean-up procedure (Sect. 2.6). 


\subsubsection{Extraction method for honeybees}

Samples of honeybees $(0.5 \mathrm{~g})$ were homogenised in cyclohexane $(10 \mathrm{~mL})$ using an Ultraturrax, set at $12000 \mathrm{rpm}$, for 1 minute. Acetonitrile $(10 \mathrm{~mL})$ was added and the sample extract mixed for 10 minutes using a flat bed shaker, set at $350 \mathrm{rpm}$, prior to centrifugation at $4500 \mathrm{rpm}$ for 10 minutes and at $30{ }^{\circ} \mathrm{C}$. An aliquot $(5 \mathrm{~mL})$ of the acetonitrile layer was removed for the clean-up procedure (Sect. 2.6).

\subsubsection{Extraction method for beeswax}

Samples of beeswax $(0.5 \mathrm{~g})$ were dissolved in cyclohexane $(10 \mathrm{~mL})$ and placed in a water bath set at $45^{\circ} \mathrm{C}$. After 10 minutes the sample extract was mixed for 10 minutes using a flat bed shaker, set at $350 \mathrm{rpm}$. Water/acetonitrile, 50/50 v/v, $(10 \mathrm{~mL})$ was added and the sample extracts then re-mixed and centrifuged as described above. An aliquot $(5 \mathrm{~mL})$ of the water/acetonitrile solution was removed for the clean-up procedure (Sect. 2.6).

\subsubsection{Extraction method for brood}

Samples of brood $(0.5 \mathrm{~g})$ were homogenised in acetonitrile $(10 \mathrm{~mL})$ using a Ultraturrax set at $12000 \mathrm{rpm}$ for 1 minute. An aliquot $(5 \mathrm{~mL})$ of acetonitrile was removed for the clean-up procedure (Sect. 2.6).

\subsection{Clean-up for non-honey samples}

\subsubsection{Chem elut clean-up method}

After extraction an aliquot $(5 \mathrm{~mL})$ of the aqueous (or acetonitrile) fraction was loaded onto a Chem elut cartridge $(5 \mathrm{~mL})$ and left to equilibrate for 5 minutes. Aliquots of dichloromethane $(2 \times$ $10 \mathrm{~mL}$ ) were applied at 10 minute intervals and the combined eluate was evaporated to dryness at 45$50{ }^{\circ} \mathrm{C}$ under a stream of nitrogen. The extract was reconstituted in 50\% hexane in ethyl acetate $(5 \mathrm{~mL})$ before SPE clean-up (Sect. 2.6.2).

\subsubsection{Solid Phase Extraction (SPE) clean-up method}

The extract from Section 2.6.1 was cleaned up using a Bond Elut $\mathrm{NH}_{2}$ cartridge conditioned with
$50 \%$ hexane in ethyl acetate $(4 \mathrm{~mL})$. The sample extract $(5 \mathrm{~mL})$ was loaded onto the cartridge, which was then washed with $50 \%$ hexane in ethyl acetate $(3 \mathrm{~mL})$ and then $5 \%$ methanol in ethyl acetate $(3 \mathrm{~mL})$. CAP was eluted with $50 \%$ methanol in ethyl acetate $(3 \mathrm{~mL})$. The eluate was evaporated to dryness at $45-50{ }^{\circ} \mathrm{C}$ under a stream of nitrogen and then reconstituted in water $(0.25-0.5 \mathrm{ml}$, depending on matrix) before quantification by LC-MS/MS (Sect. 2.9.2).

\subsection{Extraction of bound-CAP residues in honey}

The potential for CAP to form glucoside conjugates with the sugars in the honey was investigated by analyses of honey collected from dosed colonies. Two honey samples (from D28 of the dosing study) that had a CAP concentration of approximately $2 \mu \mathrm{g} / \mathrm{g}$ were weighed out ( $3.0 \mathrm{~g}$ ) in duplicate and extracted using one of the following solutions (7 mL):

- $0.06 \mathrm{mg} / \mathrm{mL}$ a-Glucosidase (from Bacillus stearothermophilus) in phosphate buffered saline (PBS) solution @ pH 6.8;

- $0.05 \mathrm{mg} / \mathrm{mL} \alpha$-Glucosidase (from Saccharomyces cerevisiae) in PBS solution @ pH 6.8;

- $0.12 \mathrm{mg} / \mathrm{mL} \beta$-Glucosidase in PBS solution @ $\mathrm{pH} 5.0$;

- HPLC grade water;

- $10 \mathrm{mM} \mathrm{HCl}$.

All enzyme solutions were diluted so that they would give 3 units $/ \mathrm{mL}$ activity following the suppliers instructions. The samples were vortex mixed and placed in a water bath at $37{ }^{\circ} \mathrm{C}$ overnight.

After extraction the eluent was then applied to a Chem elut cartridge $(10 \mathrm{~mL})$ and left for 5 minutes. One aliquot of dichloromethane $(15 \mathrm{~mL})$ was applied after 10 minutes and another aliquot $(20 \mathrm{~mL})$ 10 minutes later. The combined eluate was evaporated to dryness at $45-50{ }^{\circ} \mathrm{C}$ under a stream of nitrogen and then reconstituted in 50\% hexane in ethyl acetate $(5 \mathrm{~mL})$. The sample was then cleaned-up as described in Section 2.6.2.

\subsection{Extraction of CAP residues on the surface of beeswax}

Water $(10 \mathrm{~mL})$ was added to wax samples $(0.5 \mathrm{~g})$ and then mixed on a flat bed shaker set to $350 \mathrm{rpm}$ 
Table I. Validation of the LC-MS/MS method used for the measurement of CAP. RSD = Relative Standard Deviation. $*$ RPD $=$ Relative Percent Difference, used when $\mathrm{n}=2 . n=$ Total number of replicates analysed.

\begin{tabular}{lcccccccc}
\hline $\begin{array}{l}\text { Spike concentration } \\
(\mu \mathrm{g} / \mathrm{g})\end{array}$ & 0.003 & 0.03 & 0.3 & 3.0 \\
\hline \multicolumn{9}{c}{ Measured Concentration $\mu \mathrm{g} / \mathrm{g} / \% \mathrm{RSD}^{*},(n)$} \\
\hline Royal Jelly & 0.003 & $8.3(21)$ & 0.032 & $1.3,(2)$ & 0.32 & $2.3,(2)$ & 2.9 & $1.1,(2)$ \\
Beeswax & 0.004 & $21,(21)$ & 0.029 & $1.9,(7)$ & 0.23 & $2.7,(7)$ & 2.2 & $9.8,(2)$ \\
Bees & 0.003 & $11,(19)$ & 0.023 & $15,(7)$ & 0.30 & $15,(7)$ & 2.6 & $0.02,(2)$ \\
Brood & 0.003 & $5.3,(7)$ & 0.031 & $11,(7)$ & 0.33 & $4.3,(7)$ & 2.8 & $5.6,(7)$ \\
\hline
\end{tabular}

for 10 minutes. An aliquot $(5 \mathrm{~mL})$ of water was removed for clean up (Sect. 2.6). The wax was separated from the remaining water by filtration (Whatman No. 1) and then the wax collected in the filter paper was removed for extraction (Sect. 2.5.3) and clean up (Sect. 2.6).

\subsection{Quantification}

All honey samples were analysed using the biosensor method except for the honey samples analysed in the bound residue investigation, which were analysed by LC-MS/MS. The non-honey samples were analysed by LC-MS/MS.

\subsubsection{Surface plasmon resonance (SPR) biosensor determination}

CAP in honey samples was quantified using a published SPR biosensor method (Ashwin et al., 2005).

\subsubsection{Liquid chromatography mass spectrometry determination}

The LC-MS/MS system comprised a Quattro Ultima Platinum Triple Quadrupole (Micromass, Manchester, UK) coupled to an Alliance 2695 Separations Module (Waters) controlled by Mass Lynx version 4.0. A gradient separation was performed using a Thermo HyPurity C18 $(150 \mathrm{~mm} \times 2.1 \mathrm{~mm}$, particle size $5 \mu \mathrm{m})$ with a $\mathrm{C} 18$ guard column installed. The mobile phase was $10 \mathrm{mM}$ ammonium acetate in water/methanol, 70/30, v/v changing to $1 / 99$ over 5 minutes of the run. The flow rate was $0.2 \mathrm{~mL} / \mathrm{min}$ and the injection volume was $10 \mu \mathrm{L}$. The LC-MS/MS was operated using electrospray in the negative ion mode and the transitions monitored were; for CAP $m / z 321>152$ and $m / z, 321>257$; for CAP-d5 $m / z$ 326 $>157$ and $m / z, 326>262$.

\subsection{Method validation}

Method validation information for the analysis of honey is presented with the published method used (Ashwin et al., 2005). Quality control samples were spiked in the range of $1-20 \mu \mathrm{g} / \mathrm{g}(1,2.5,5,10$ and $20 \mu \mathrm{g} / \mathrm{g}$ ) and the mean calculated recovery was $64 \%(\mathrm{n}=17$, range 49-83\%).

Results obtained from method validation studies of other matrices are also presented in Table I with associated analytical control data obtained during analysis of samples.

\subsection{Statistical analysis}

A linear mixed model analysis was performed on each of the sample sets separately. The individual hive was used as a random effect to allow for repeated measures over time on the same hive. The location of the sample was also used as a random effect, which allowed for variation between locations, but these differences were not of quantifiable interest. Time, treatment and a time by treatment interaction were investigated as fixed effects during the modeling.

For each treatment pairwise comparisons were made between time points, to show how the concentration profile changed with time. Up to 66 pairwise comparisons were made per commodity and therefore a Bonferroni adjustment for multiplicity was used when the significance level was assessed, i.e. divide the $5 \%$ level by the number of comparisons being made, to get a new significance level.

Genstat $\Re^{9}$.2 software was used for all statistical analysis. 
Table II. CAP residue concentrations in honey collected from non-shook swarm colonies over a period of 48 weeks after dosing $(n=$ number of honey samples analysed from all hives per time point $)$. SD $=$ Standard Deviation.

\begin{tabular}{lccc}
\hline $\begin{array}{l}\text { Time point } \\
\text { (Days from dosing) }\end{array}$ & $\begin{array}{c}\text { Mean of pooled } \\
\text { results for brood } \\
\text { and super honey } \\
\mu \mathrm{g} / \mathrm{g} \pm \mathrm{SD}\end{array}$ & $\begin{array}{c}\text { Brood honey mean } \\
\text { residue } \mu \mathrm{g} / \mathrm{g} \pm \mathrm{SD}, \\
(n)\end{array}$ & $\begin{array}{c}\text { Super honey mean } \\
\text { residue } \mu \mathrm{g} / \mathrm{g} \pm \mathrm{SD}, \\
(n)\end{array}$ \\
\hline D3 & $17 \pm 19$ & $24 \pm 26,(4)$ & $10 \pm 5.2,(4)$ \\
D7 & $26 \pm 7.2$ & $31 \pm 4.9,(4)$ & $20 \pm 3.6,(3)$ \\
D14 & $11 \pm 2.7$ & $12 \pm 2.2,(4)$ & $11 \pm 3.5,(4)$ \\
D21 & $3.5 \pm 1.6$ & $3.7 \pm 1.8,(4)$ & $3.4 \pm 1.6,(4)$ \\
D28 & $2.0 \pm 0.86$ & $1.8 \pm 0.71,(8)$ & $2.3 \pm 1.0 .(8)$ \\
D56 & $2.5 \pm 2.0$ & $1.7 \pm 1.8,(4)$ & $3.3 \pm 2.0,(4)$ \\
D84 & $1.4 \pm 0.65$ & $1.4 \pm 0.78,(4)$ & $1.4 \pm 0.60,(4)$ \\
D126 & $0.69 \pm 0.40$ & $0.35 \pm 0.15,(4)$ & $1.0 \pm 0.21,(4)$ \\
D332 (over winter) & $1.0 \pm 1.0$ & $0.38 \pm 0.26,(4)$ & $1.6 \pm 1.2,(4)$ \\
\hline
\end{tabular}

Table III. Results of the LC-MS/MS measurement of CAP in honey (taken at D28 of the dosing study) with and without treatments to release glucoside bound residues.

\begin{tabular}{lcc}
\hline & \multicolumn{2}{c}{ Concentration $\mu \mathrm{g} / \mathrm{g}$} \\
\hline & Sample 1 & Sample 2 \\
\cline { 2 - 3 }$\alpha$ - glucosidase (from Bacillus stearothermophilus) & 1.9 & 2.2 \\
$\alpha$ - glucosidase (from Saccharomyces cerevisiae) & 1.8 & 2.0 \\
$\beta$ - glucosidase & 1.8 & 2.0 \\
Acid (10 mM HCl) & 1.7 & 2.0 \\
Water (control) & 1.8 & 2.0 \\
\hline
\end{tabular}

Results are the average of duplicate analyses.

\section{RESULTS}

\subsection{Residue concentrations in honey}

\subsubsection{Residue concentrations in honey collected from dosed colonies (without shook swarm treatment)}

The concentrations of CAP in the samples of brood and super honey are shown in Table II. The concentration of chloramphenicol in honey control samples collected two days before dosing (D-2) were all $<0.0003 \mu \mathrm{g} / \mathrm{g}$. The highest mean concentration (results for the brood and super honey pooled together) of CAP in honey was $26 \mu \mathrm{g} / \mathrm{g}$ at D7, declining to $1.4 \mu \mathrm{g} / \mathrm{g}$ at D84 and $1.0 \mu \mathrm{g} / \mathrm{g}$ at D332. Statistical analysis confirms, that with the exception of D3 compared to D14, the concentrations of CAP at D3 and D7 are significantly higher $(P=0.001)$ compared to the concentrations measured at all later time points.

The results from this study (Tab. III) demonstrate there was no significant difference between the concentration of unbound (water extracted) CAP and total (sum of free and bound) CAP. The total CAP was determined using enzymes or acid to cleave the glucoside bonds. The apparent bound residues of CAP were approximately $8 \%$ of the total and is within analytical variation.

\subsubsection{Residue concentration in honey collected from dosed colonies (shook swarmed)}

Prior to the shook swarm treatment the initial concentrations of CAP measured in honey 


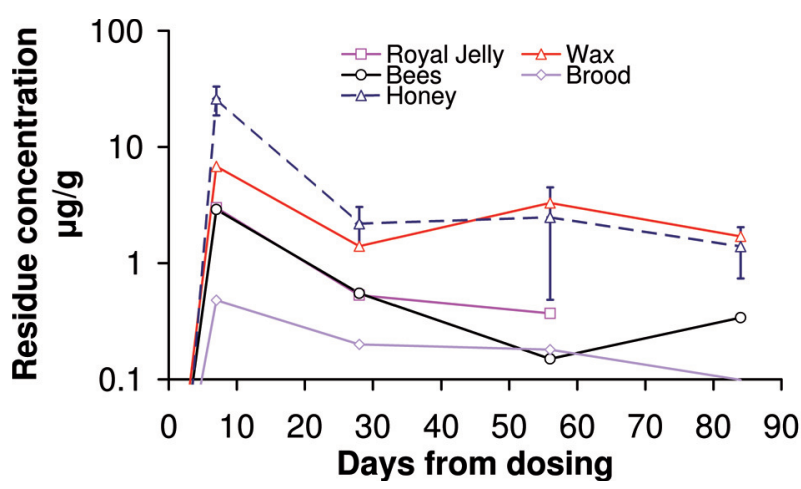

Figure 2. Results from 4 non-shook swarmed colonies; Concentration of CAP in honey (pooled brood and super results), royal jelly, wax, bees and brood collected from 4 non-shook swarmed colonies 0 to 84 days; after dosing with CAP.

are similar for all dosed colonies. After the shook swarm treatment the mean concentration of CAP were up to one order of magnitude lower than those colonies that did not undergo the treatment. The mean concentrations measured for the shook swarmed colonies were $26 \mu \mathrm{g} / \mathrm{g}$ at D7, $0.41 \mu \mathrm{g} / \mathrm{g}$ at D56, $0.20 \mu \mathrm{g} / \mathrm{g}$ at D126 and a final concentration of $0.091 \mu \mathrm{g} / \mathrm{g}$ at D332 (post winter sample). No samples were available at D 84.

\subsection{Residue concentrations in non-honey samples}

The residue concentration of CAP in royal jelly, wax, adult bees and brood, 0 to 84 days after dosing are presented in Figure 2. Residue concentrations of CAP were all $<0.003 \mu \mathrm{g} / \mathrm{g}$ in brood, and $<0.03 \mu \mathrm{g} / \mathrm{g}$ for wax and bees in the control samples collected at D-2. Subsequent control samples for all non-honey samples tested negative for the presence of CAP.

There were relatively few samples of royal jelly available for collection during the study; 4, 2 and 3 samples were collected at D7, D28, D56, respectively. No statistical analysis was carried out due to the low number of samples at each time point. The concentration of CAP in royal jelly was always lower than in honey. The highest concentration of CAP detected in royal jelly was $3.0 \mu \mathrm{g} / \mathrm{g}$ at D7, declining to $0.4 \mu \mathrm{g} / \mathrm{g}$ at D56.
Four bee samples were collected at all time points except D28 where only 3 were available. The highest mean concentration of CAP in bees was $2.9 \mu \mathrm{g} / \mathrm{g}$, at D7, declining to $0.34 \mu \mathrm{g} / \mathrm{g}$ at D84 with standard deviations of 1.0 and 0.21 , respectively. Statistical analysis $(P \leq 0.001)$ for bees showed that D-2, D28, D56 and D84 samples contain significantly less CAP than those taken at D7.

Four samples of brood were collected at D-2, D7 and D28, 3 collected at D56 and D84. The highest mean concentration of CAP in brood was $0.48 \mu \mathrm{g} / \mathrm{g}$, at D7, declining to $0.10 \mu \mathrm{g} / \mathrm{g}$ at D84 with standard deviations of 0.26 and 0.066 , respectively. For the brood samples D-2 and D84 contain significantly less CAP $(P \leq 0.001)$ than D7.

The highest mean concentration in beeswax was $6.8 \mu \mathrm{g} / \mathrm{g}$, at D7, declining to $1.7 \mu \mathrm{g} / \mathrm{g}$, at D84 with standard deviations of 5.3 and 0.87 , respectively ( $\mathrm{n}=4$, all time points). Statistical analysis $(P \leq 0.001)$ showed that the concentrations of CAP at D-2, D28 and D84 are not significantly different but are all significantly less than the CAP concentration at D7. Since the concentration of CAP was much higher in wax compared to other non-honey matrices additional samples were selected at random, to assess if CAP residues were associated with the surface of the wax (in contact with the honey) or encapsulated within the wax. These results (Fig. 3) show that surface residues can contribute between $4-78 \%$ of the total measured residue of CAP in beeswax. 


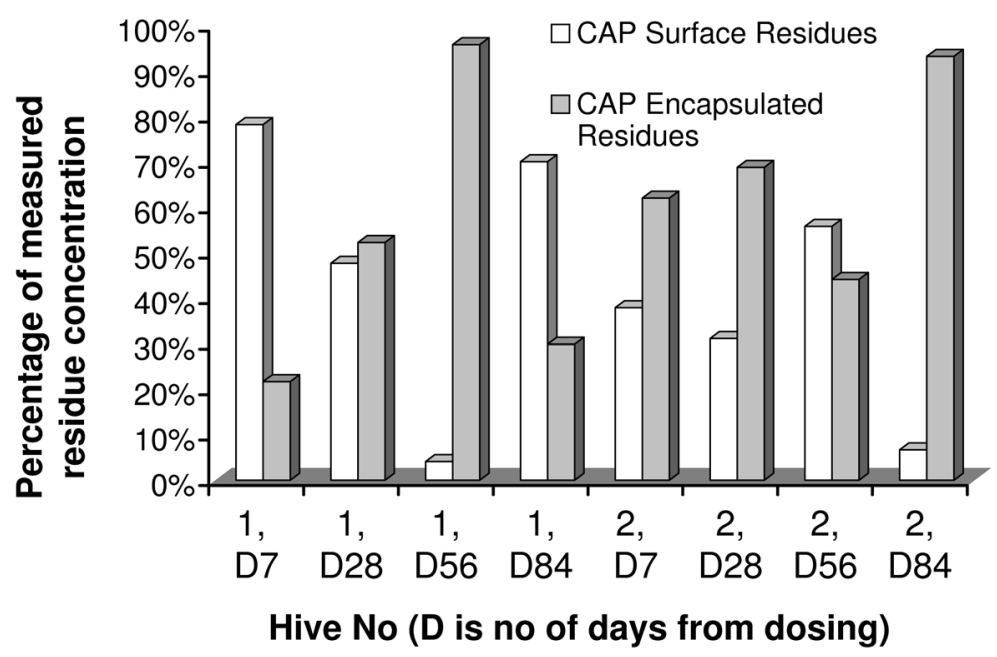

Figure 3. Percentage of CAP as; (a) surface residues by extraction with water (b) encapsulated residues extracted by solvent after removal of surface residues.

\section{DISCUSSION}

The depletion profile of CAP in honey displays a similar trend to the depletion profiles for oxytetracycline and tylosin (Thompson et al., 2006; Adams et al., 2007). There is a 'peak' concentration measured at D7 with a corresponding drop in concentration over the next 21 days (>D7 to D28). This decline in the concentrations is due primarily to the dilution of the CAP into the 'honey flow'. For the remaining period D28 to D332 a baseline concentration of CAP is maintained with no significant reduction in the residue concentrations. CAP was detected in all over winter (D332) honey samples; including samples from shook swarm colonies.

The detection of CAP contaminated honey in blended honey should also be considered. Assuming a dose of $1 \mathrm{~g}$ of CAP in $250 \mathrm{~mL}$ $50 \%$ sucrose solution, taking into account the detection limit $(0.0003 \mu \mathrm{g} / \mathrm{g})$ of the Biosensor and LC-MS/MS methods and the concentrations of CAP in honey (D332) from dosed hives of this study, a 100-fold dilution with uncontaminated honey would not prevent detection of CAP misuse.

The observation that CAP did not form significant concentrations of glucosides in the honey supports the use of free CAP as a suit- able marker compound for detection and quantification of CAP residues in honey. This situation contrasts to mammalian systems where up to $90 \%$ of the excretory forms of CAP are CAP N-acetyl conjugate (Cooper et al., 1998).

The results for the non-honey samples from the other hive compartments show a similar trend to those observed with residue concentrations in honey. The highest concentrations occur around D7 and then the concentrations decline rapidly to a much lower concentration at D28, remaining stable at the lower concentration until D84. With the exception of beeswax the absolute mean concentrations are considerably lower (one order of magnitude for royal jelly, bees and brood) than those in honey. The mean concentrations observed in wax are similar to those in honey, possibly due to the partitioning between the two compartments, which are in direct contact with each other. There is evidence that beeswax can act as a reservoir for chemicals within the beehive. If CAP contaminated beeswax was used as foundation for other colonies then the CAP could partition back into the honey. Tremolada et al. (2004) reported the partitioning of coumaphos from beeswax into honey.

The results from the shook swarm experiment show bees can also act as a reservoir for CAP, which can be transferred to fresh honey. 
Samples of honey collected at D56, after transfer of the bees to clean foundation contained a mean concentration of $0.41 \mu \mathrm{g} / \mathrm{g}$ CAP. The bees are the only 'compartment' of the original hive, which was transferred during application of the shook swarm method.

In conclusion, CAP is a suitable marker compound to detect and quantify the use of CAP in apiculture. Contamination of all compartments in the hive system occurs rapidly within 7 days from dosing. The shook swarm procedure does not completely remove CAP from the system as the bees can act as a reservoir and transfer CAP to the clean hive.

\section{ACKNOWLEDGEMENTS}

The authors thank Simon Hird and his colleagues for undertaking the LC-MS/MS measurements, Alison Colyer for undertaking the statistical analyses and the Veterinary Medicines Directorate, Defra, for funding (project No. VM02140).

Étude de la répartition et de la déplétion des résidus de chloramphénicol dans les produits de la ruche provenant de colonies d'abeilles (Apis mellifera).

miel / gelée royale / cire d'abeille / chloramphénicol / résidu

\footnotetext{
Zusammenfassung - Untersuchungen zu Verteilung und Abbau von ChloramphenikolRückständen in Bienenprodukten aus behandelten Honigbienenvölkern (Apis mellifera). In mehreren veröffentlichten Studien ist Chloramphenikol (CAP) in Honig und Gelee Royale nachgewiesen worden. Es wird häufig zur Bekämpfung der Amerikanischen Faulbrut (AFB) in Bienenvölkern eingesetzt. Allerdings sind nach EU-Bestimmungen keinerlei CAP-Rückstände in Nahrungsmittel erlaubt, da CAP aplastische Anämie verursachen kann, eine seltene aber schwerwiegende Blutkrankheit. Das Ziel dieser Untersuchung war es, die Verteilung und den Abbau von CAP innerhalb behandelter Bienenvölker $\mathrm{zu}$ erfassen.

Bienenvölker wurden mit 1,0 g CAP pro Volk als Einzeldosis in Zuckerlösung behandelt. Honigproben wurden über einen Zeitraum von 48 Wochen und Proben von Gelee Royale, Bienenwachs, Bienen und Brut über einen Zeitraum von 12 Wochen regelmäßig entnommen. Über eine Biosensor-Methode und/oder mit einem LC-
}

MS/MS-Analyseverfahren wurden die Konzentrationen von CAP in den Proben bestimmt.

In Honig erreichten die CAP-Konzentrationen 7 Tage nach Applikation einen Maximalwert von $26 \mu \mathrm{g} / \mathrm{g}$. Zwischen Tag 7 und Tag 28 wurde dann ein rascher Abbau des CAP festgestellt. Zwischen Tag 56 und Tag 332 stellte sich beim Honig schließlich eine Basiskonzentration zwischen 2,5 $\mu \mathrm{g} / \mathrm{g} 1,0 \mu \mathrm{g} / \mathrm{g}$ ein (Tab. II). Die übrigen Proben zeigten einen ähnlichen Trend (Abb. 2) mit einer Maximalkonzentration von CAP am 7. Tag und einem darauf folgenden raschen Abfall auf eine relativ stabile Basiskonzentration.

Als ein mögliches Instrument zur Reduzierung der CAP-Rückstände wurde die Kunstschwarmbildung untersucht. In Proben, die nach der Kunstschwarmbildung entnommen wurden, war die CAP-Konzentration im Honig durchschnittlich 10 Mal geringer als in Völkern ohne Kunstschwarmbildung, allerdings war CAP mit der Biosensor-Methode nach wie vor nachweisbar.

Ebenfalls geprüft wurde die Möglichkeit, dass ,gebundene Rückstände“ durch Reaktionen von CAP mit Zuckerkomponenten entstehen. Es konnten aber keine signifikanten bindungsabhängigen Rückstände in den untersuchten Proben nachgewiesen werden (Tab. III).

Der Nachweis von CAP in allen untersuchten Proben zeigt, dass CAP innerhalb von 7 Tagen nach Anwendung über alle Bereiche des Bienenvolkes verteilt wird. Der Nachweis von CAP 332 Tage nach Applikation bestätigt die Persistenz des Antibiotikums in Bienenvölkern. Selbst nach Anwendung des Kunstschwarmverfahrens kann CAP mit den heutigen Analysemethoden noch nachgewiesen werden.

\section{Chloramphenikol / Honig / Bienen / Gelee Roya-} le / Bienenwachs

\section{REFERENCES}

Adams S.J., Heinrich K., Hetmanski M., Fussell R.J., Wilkins S., Thompson H.M., Sharman M. (2007) Study of the depletion of tylosin residues in honey extracted from treated honeybee (Apis mellifera) colonies and the effect of the shook swarm procedure, Apidologie 38, 315-322.

Ashwin H.M., Stead S.L., Taylor J.C., Startin J.R., Richmond S.F., Homer V., Bigwood T., Sharman M. (2005) Development and validation of screening and confirmatory methods for the detection of chloramphenicol and chloramphenicol glucuronide using SPR biosensor and liquid chromatography-tandem mass spectrometry, Anal. Chim. Acta 529, 103-108.

Calvarese S., Forti A.F., Scortichini G., Diletti G. (2006) Chloramphenicol in royal jelly: analytical aspects and occurrence in Italian imports, Apidologie 37, 673-678. 
Cooper A.D., Tarbin J.A., Farrington W.H.H., Shearer G. (1998) Aspects of extraction, spiking and distribution in the determination of incurred residues of chloramphenicol in animal tissues, Food Addit. Contam. 15, 6, 637-644.

Council Regulation 2377/90 (1990) Laying down a Community procedure for the establishment of maximum residue limits of veterinary medicinal products in foodstuffs of animal origin, Off. J. L224, 1-8.

Commission Decision 2003/181/EC (2003) Amending Decision 2002/657/EC as regards the setting of minimum required performance limits (MRPLs) for certain residues in food of animal origin, Off. J. L71, 17-18.

Fujita K., Osuka H., Fujiki T., Yoneyama S., Sengoku K., Sumiya Y., Watanabe M., Mizutani Y., Zhao X., Hirose T. (2005) Inter-laboratory validation studies of analytical method for determination of chloramphenicol in royal jelly, J. Food Hyg. Soc. Jpn 46, 294-297.

Ishh R., Horie M., Murayama M., Maitani T. (2006) Analysis of chloramphenicol in honey and royal jelly by LC/MS/MS, J. Food Hyg. Soc. Jpn 47, 5865.

Kochansky J., Knox D.A., Feldlaufer M., Pettis J.S. (2001) Screening alternative antibiotics against oxytetracycline-susceptible and resistant Paenibacillus larvae, Apidologie 32, 215-222.

McMullen S.E., Lansden J.A., Schenck F.J. (2004) Modifications and adaptations of the Charm II rapid antibody assay for chloramphenicol in honey, J. Food Prot. 67, 7, 1533-1536.

Thompson H.M., Waite R.J., Wilkins S., Brown M.A., Bigwood T., Shaw M., Ridgway C., Sharman M. (2006) Effects of shook swarm and supplementary feeding on oxytetracycline levels in honey extracted from treated colonies, Apidologie 37, 51-57.

Tremolada P., Bernardinelli I., Colombo M., Spreafico M., Vighi M. (2004) Coumaphos distribution in the hive ecosystem: case study for modelling Applications, Ecotoxicology 13, 589-601.

Wen X., Huiying D., Xiaodong Z., Ziqiang Z., Junyang X., Chunyan Y. (2005) Determination of chloramphenicol residue in honey and royal jelly by high performance liquid chromatography/mass spectrometry/mass spectrometry, Chin. J. Anal. Chem. 33, 1767-1770.

Verzegnassi L., Royer D., Mottier P., Stadler R.H. (2003) Analysis of chloramphenicol in honeys of different geographical origin by liquid chromatography coupled to electrospray ionization tandem mass spectrometry, Food Addit. Contam. 20, 335342.

Veterinary Residues Committee (VRC) (2006) Announcement on the results of the brand naming survey of chloramphenicol, nitrofurans and streptomycin in honey, [on-line] http://www.vetresidues-committee.gov.uk (accessed on 7 June 2007). 